JFFI. 2018; 5(1) 253-257

www.jurnal.farmasi.umi.ac.id/index.php/fitofarmakaindonesia

\title{
ISOLASI DAN KARAKTERISASI BAKTERI ASAM LAKTAT DARI LIMBAH CAIR RENDAMAN KACANG KEDELAI
}

\author{
Zakiyah Zahra Nur Amaliah ${ }^{1}$, Saiful Bahri' ${ }^{2}$, dan Puteri Amelia ${ }^{1}$ \\ ${ }^{1}$ Prodi Farmasi, Fakutas Kedokteran dan Ilmu Kesehatan, UIN Syarif Hidayatullah Jakarta \\ ${ }^{2}$ Prodi Farmasi, Institut Sains dan Teknologi Nasional, Srengseng Sawah, Jakarta Selatan \\ 1puteri.amelia@uinjkt.ac.id
}

\begin{abstract}
Tempe is an Indonesia traditional food, which in the manufacturers have a liquid waste that no use again namely soybean soaking water. Lactic Acid Bacteria (LAB) has been known at every stage of tempeh production, included at soaking soybeans. This study aimed to isolate and characterize LAB contained in soybean soaking water liquid waste. After serial dilution to 10-7, soybean soaking water liquid waste was inoculated on the MRSA contained 1\% CaCO3. After incubation, there are 8 isolates which produce clear zone around their colonies with different colony morphology suspected as LAB. Morphological, physiological and biochemical characteristics were employed to identify LAB. All isolates were non-spore forming, non-motile, catalase negative, grow well at $37^{\circ}$ and $45^{\circ} \mathrm{C}$, could be able to grow in the presence of $4 \%$ and $6.5 \%$ sodium chloride. The results of safety test showed all isolates negative for hemolytic activity. Seven of eight isolates are Gram-positive, while one is a Gram-negative. But only Grampositive were chosen as they represent the LAB characteristic. Seven isolates were identified as Lactobacillus with heterofermentative as the type fermentation. In this study, Lactobacillus casei ATCC 393 used as reference strain
\end{abstract}

Keywords: Characterization, isolation, lactic acid bacteria, soybean soaking water

\section{PENDAHULUAN}

Proses fermentasi merupakan salah satu metode pengawetan yang dapat dideskripsikan sebagai suatu proses perubahan secara biokimia pada bahan pangan oleh aktivitas mikroorganisme (Hidayat dan Sri, 2006). Mikroorganisme tersebut memanfaatkan beberapa komponen bahan dasar pangan sebagai substrat untuk menghasilkan energi dan komponen seluler, meningkatkan populasi, dan menghasilkan beberapa produk yang tidak digunakan sebagai produk akhir yang disekresikan ke lingkungan.

Proses fermentasi dapat meningkatkan nilai gizi bahan yang berkualitas rendah, yang merupakan suatu cara untuk menghilangkan zat antinutrisi dan racun yang terkandung dalam suatu bahan makanan (Sopandi dan Wardah, 2014).

Pangan yang diperoleh dari proses fermentasi banyak berasal dari biji-bijian, salah satu diantaranya kacang kedelai yang banyak digunakan sebagai bahan dasar dari pangan fermentasi seperti tempe, kecap, dan tauco. Tempe adalah makanan hasil fermentasi tradisional Indonesia.

Banyak penelitian dan review telah dilakukan mengenai tempe serta keberadaan dari BAL pada tempe pun telah dilaporkan (Kormin, et al., 2001; Moreno, et al., 2002). Pada tahun 2013 dan 2015, Pisol, et al.berhasil mengisolasi BAL dari tempe, dimana dilakukan tidak hanya pada produk tempe namun pada tiap langkah pembuatan tempe, namun didapatkan hasil yang berbeda.

Pada proses pembuatan tempe di pabrik, dilakukan terlebih dahulu perebusan kacang kedelai lalu didiamkan selama semalaman, setelah itu baru dilakukan proses pembuatan tempe selanjutnya. Air rendaman tersebut biasanya tidak digunakan kembali sehingga akan dibuang begitu saja atau terkadang digunakan juga sebagai pakan cair ternak. Melihat ketersediaannya yang banyak serta tidak dimanfaatkan kembali, air rendaman kedelai tersebut atau limbah cair ini dapat diteliti lebih lanjut mengenai kandungan Bakteri Asam Laktat (BAL) didalamnya.

Penelitian ini bertujuan untuk mengisolasi BAL dari limbah cair rendaman kacang kedelai yang diharapkan dapat memberi informasi mengenai keberadaan dan karakteristik BAL dari limbah cair rendaman kacang kedelai pada produsen tempe.

\section{METODE PENELITIAN A. Bahan}

Bahan utama yang digunakan dalam penelitian ini adalah sampel limbah cair air rendaman kacang kedelai dari satu produsen tempe yang berlokasi di Pancoran, Jakarta Selatan. Bahan lainnya yaitu $\mathrm{NaCl}$, kalsium karbonat (CaCO3), media MRS 
Agar (Merck), media MRS broth (Conda pronadisa), media SIM (Merck), pepton water (Merck), media blood agar, pewarna Gram, pewarna endospora, aquadest, hidrogen peroksida (H2O2) 3\%, minyak imersi, dan alkohol $70 \%$.

\section{B. Peralatan}

Peralatan yang digunakan pada penelitian adalah kaca objek, jarum ose, batang spreader, pembakar spirtus, kaca objek, tabung reaksi, beaker glass, erlenmeyer, cawan petri, mikropipet (Thermo Scientific), termometer, vortex, timbangan analitik (Ogawa Seiki), anaerobic jar (Oxoid), mikroskop optik, pH meter (Horiba, Jepang), autoklaf digital (Ogawa Seiki), inkubator (France Etuves), laminar air flow, lemari pendingin (GEA), dan oven (Memmert).

\section{Prosedur}

\section{Isolasi Bakteri Asam Laktat}

Sebanyak $1 \mathrm{~mL}$ dari sampel secara aseptis ditambahkan ke dalam $9 \mathrm{~mL}$ pepton water steril $(0,1 \%, \mathrm{~b} / \mathrm{v})$ dan dihomogenkan. Kemudian, dilakukan pengenceran bertingkat sampai pengenceran ke-7. Diambil 0,1 mL cuplikan dari tiga seri pengenceran terakhir dan dikulturkan pada MRS Agar tersuplementasi $\mathrm{CaCO} 31 \%$ menggunakan metode spread plate. Diinkubasi selama 48 jam pada inkubator suhu $37^{\circ} \mathrm{C}$. Koloni yang tumbuh dihitung dan jumlah totalnya dihitung menggunakan metode total plate count (TPC).

\section{Pemurnian}

Koloni yang tumbuh dengan zona bening disekelilingnya dilakukan pemurnian sel dengan cara menggoreskan pada media MRSA tersuplementasi $\mathrm{CaCO} 31 \%$ dengan metode kuadran diinkubasi selama 24 jam pada inkubator suhu $37^{\circ} \mathrm{C}$ agar diperoleh koloni tunggal untuk selanjutnya disubkultur kembali sebagai isolat tunggal murni.

\section{Karakterisasi Isolat Bakteri Asam Laktat}

Karakterisasi isolat meliputi morfologi, fisiologi, dan biokimia. Karakterisasi morfologi terdiri dari pewarnaan Gram, pewarnaan endospora, dan uji motilitas, sedangkan karakterisasi fisiologi dan biokimia teridiri dari uji katalase, produksi gas, suhu, dan garam.

a. Pewarnaaan Gram: diteteskan $\mathrm{NaCl}$ fisiologis pada kaca ojek isolat lalu diambil satu ose isolat dari agar miring. Isolat tersebut disebarkan pada kaca objek lalu difiksasi. Gentian violet diteteskan diatas preparat dan biarkan selama 1 menit. Preparat dicuci dengan air mengalir. Cairan lugol diteteskan pada preparat kemudian dibiarkan kembali selama 1 menit. Preparat dicuci dan diteteskan dengan alkohol $96 \%$ selama 30 detik. Preparat dicuci dengan air mengalir. Terakhir, preparat diteteskan dengan safranin dan dibiarkan selama 45-60 detik. Preparat dicuci dan dikeringkan untuk diamati dibawah mikroskop. Bakteri Gram positif akan berwarna ungu dan bakteri Gram negatif berwarna merah.

b. Pewarnaan endospora: Preparat yang telah difiksasi diletakkan diatas penangas air lalu ditutup dengan kertas saring. Malakit hijau diteteskan dan dibiarkan selama 5 menit. Preparat dicuci dengan air mengalir. Dilakukan kembali pewarnaan dengan safranin kemudian biarkan selama 60 detik. Preparat dicuci, hasilnya diamati dibawah mikroskop. Endospora akan berwarna hijau sedangkan sel vegetatif akan berwarna merah (Harley, 2005)

c. Uji motilitas dilakukan dengan media setengah padat, diambil sebanyak satu ose isolat bakteri dan diinokulasikan secara vertikal pada media SIM. Kemudian diinkubasi selama 48 jam pada suhu $37^{\circ}$ C. Hasil uji motilitas bakteri positif dapat dilihat dengan adanya pertumbuhan bakteri pada permukaan media atau tidak hanya bekas pada tusukan, sedangkan bakteri non motil tumbuh sepanjang tusukan (Harley, 2005).

d. Uji katalase dilakukan dengan menggunakan hidrogen peroksida (H2O2) 3\%. Isolat diambil dari stok kultur dan diletakkan pada kaca objek. Satu sampai dua tetes $\mathrm{H} 2 \mathrm{O} 23 \%$ ditambahkan ke isolat. Jika terbentuk gelembung mengindikasikan bakteri positif katalase, dan jika tidak maka mengindikasikan bakteri negatif katalase (Harley, 2005).

e. Uji produksi gas dilakukan dengan menumbuhkan kultur isolat dalam media MRS broth dalam tabung reaksi yang diberi tabung durham dengan keadaan terbalik untuk menangkap gas yang dihasilkan. Lalu diinkubasi selama 2 hari pada suhu $37^{\circ} \mathrm{C}$ (Romadhon, et al., 2012).

f. Ditumbuhkan pada temperatur yang berbedabeda dengan menggunakan MRS broth kemudian diinkubasi selama $2 \times 24$ jam dengan seri temperatur $10^{\circ} \mathrm{C}, 37^{\circ} \mathrm{C}$, dan $45^{\circ} \mathrm{C}$. Adanya pertumbuhan diamati dengan adanya kekeruhan dalam tabung (Anastiawan, 2014).

g. Untuk pertumbuhan pada konsentrasi garam $4 \%$ dan $6.5 \%$, satu ose kultur dimasukkan ke dalam MRS broth yang tersuplementasi $\mathrm{NaCl}$ masingmasing berkonsentrasi $4 \%$ dan $6.5 \%$. Lalu diinkubasi pada temperatur $37^{\circ} \mathrm{C}$ selama 24 jam. Kekeruhan menandakan adanya pertumbuhan (Thakkar, et al., 2015). 


\section{Uji Keamanan Isolat Bakteri Asam Laktat}

Isolat BAL diuji keamanannya dengan blood agar yang mengandung 5\% darah domba. Isolat dari agar miring diambil satu ose lalu diinokulasi ke media blood agar. Media tersebut kemudian diinkubasi secara anaerob pada suhu $37^{\circ} \mathrm{C}$ selama 48 jam. Pengamatan dilakukan terhadap koloni yang tumbuh, jika terdapat zona jernih disekitar koloni maka menunjukkan reaksi positif beta hemolisis. Pada uji ini, Staphylococcus aureus digunakan sebagai kontrol positif (Thakkar, et al., 2015).

\section{HASIL DAN PEMBAHASAN Isolasi Bakteri Asam Laktat}

Pada tahap awal isolasi, sampel diinokulasi ke dalam media MRSA tersuplementasi $\mathrm{CaCO}_{3} \quad 1 \%$. Didapatkan data total plate count (TPC) keseluruhan bakteri yang tumbuh sebanyak 4,99 $\times 10^{9}$ koloni/mL sedangkan TPC BAL sebanyak 9,17 $\times$ $10^{8}$ koloni/mL. Dari keseluruhan kultur bakteri yang tumbuh terpilih delapan isolat BAL yang memiliki karakteristik secara makroskopik berbeda.

Isolat yang dipilih merupakan isolat yang memiliki zona bening disekitar koloni, zona tersebut terbentuk karena produksi asam organik dari bakteri sehingga $\mathrm{CaCO}_{3}$ pada media MRSA terhidrolisis (Sun, et al., 2014; Pisol, et al., 2015).

\section{Karakterisasi Isolat Bakteri Asam Laktat}

Setelah didapatkan stok kultur, kedelapan isolat serta strain acuan dikarakterisasi dimana BAL memiliki ciri-ciri katalase negatif, Gram positif, non motil, dan tidak membentuk spora (Bulut, 2003; Surono, 2004; Sun, et al., 2014). Pewarnaan Gram merupakan tahapan penting untuk mengkarakterisasi apakah isolat adalah BAL atau bukan.

Satu isolat berwarna merah pada selnya yang berarti merupakan Gram negatif dimana isolat ini tidak memenuhi syarat BAL. Ketujuh isolat berwarna ungu pada selnya yang berarti merupakan Gram positif sehingga dilakukan uji selajutnya yaitu uji katalase.

Uji katalase digunakan untuk mengetahui adanya enzim katalase pada isolat bakteri. Hasil uji katalase menunjukkan hasil yang negatif pada kedelapan isolat dan strain acuan, dimana tidak terdapatnya gelembung gas yang terbentuk. Pada uji ini digunakan Staphylococcus aureus yang sudah diketahui memiliki enzim katalase sebagai kontrol positif, hasil uji katalase pada bakteri ini menunjukkan terbentuknya gelembung gas setelah diteteskan $\mathrm{H}_{2} \mathrm{O}_{2} 3 \%$ (Dewi, 2013).
Hasil uji pewarnaan spora menunjukkan ketujuh isolat bakteri serta strain acuan tidak membentuk spora. Ketujuh isolat dan strain acuan memberikan hasil uji motilitas yaitu non motil, yang berarti bakteri tidak memiliki flagela. Hasil ini dapat dilihat dari tidak menyebarnya pertumbuhan bakteri pada media SIM, melainkan hanya tumbuh pada bekas tusukan jarum inokulum saja.

Uji produksi gas dilakukan untuk melihat aktivitas metabolisme BAL, dimana dikelompokkan menjadi dua sub grup yaitu homofermentatif dan heterofermentatif. Dari hasil uji didapatkan strain acuan tidak memproduksi gas yang berarti memiliki tipe fermentasi homofermentatif. Sedangkan, tujuh isolat uji lainnya memproduksi gas atau termasuk ke dalam tipe fermentasi heterofermentatif.

Uji fisiologis selanjutnya adalah uji ketahanan hidup bakteri pada suhu yang berbedabeda yaitu $10^{\circ}, 37^{\circ}$, dan $45^{\circ} \mathrm{C}$, didapatkan data yang seragam yakni tidak adanya pertumbuhan pada suhu $10^{\circ} \mathrm{C}$ dan tumbuh pada suhu $37^{\circ}$ serta $45^{\circ} \mathrm{C}$. Uji ketahanan hidup bakteri pada konsentrasi garam berbeda-beda dilakukan pada kondisi lingkungan dengan konsentrasi $\mathrm{NaCl} 4 \%$ dan 6,5\%. Hasil yang didapatkan pada uji ini pun seragam yaitu ketujuh isolat serta strain acuan dapat hidup pada kedua konsentrasi tersebut.

Berdasarkan hasil pengujian sifat morfologi, fisiologi, dan biokimia bakteri yang diisolasi dari limbah cair rendaman kacang kedelai, diduga jenis bakteri yang terdapat di dalamnya merupakan bakteri asam laktat. Data hasil pengujian dapat dilihat pada Tabel 1, dengan melakukan penelusuran pada buku Bergey's Manual of Determinative Bacteriology, ketujuh isolat tersebut merupakan genus Lactobacillus. 
Tabel 1. Karakteristik Isolat BAL dan Strain Acuan

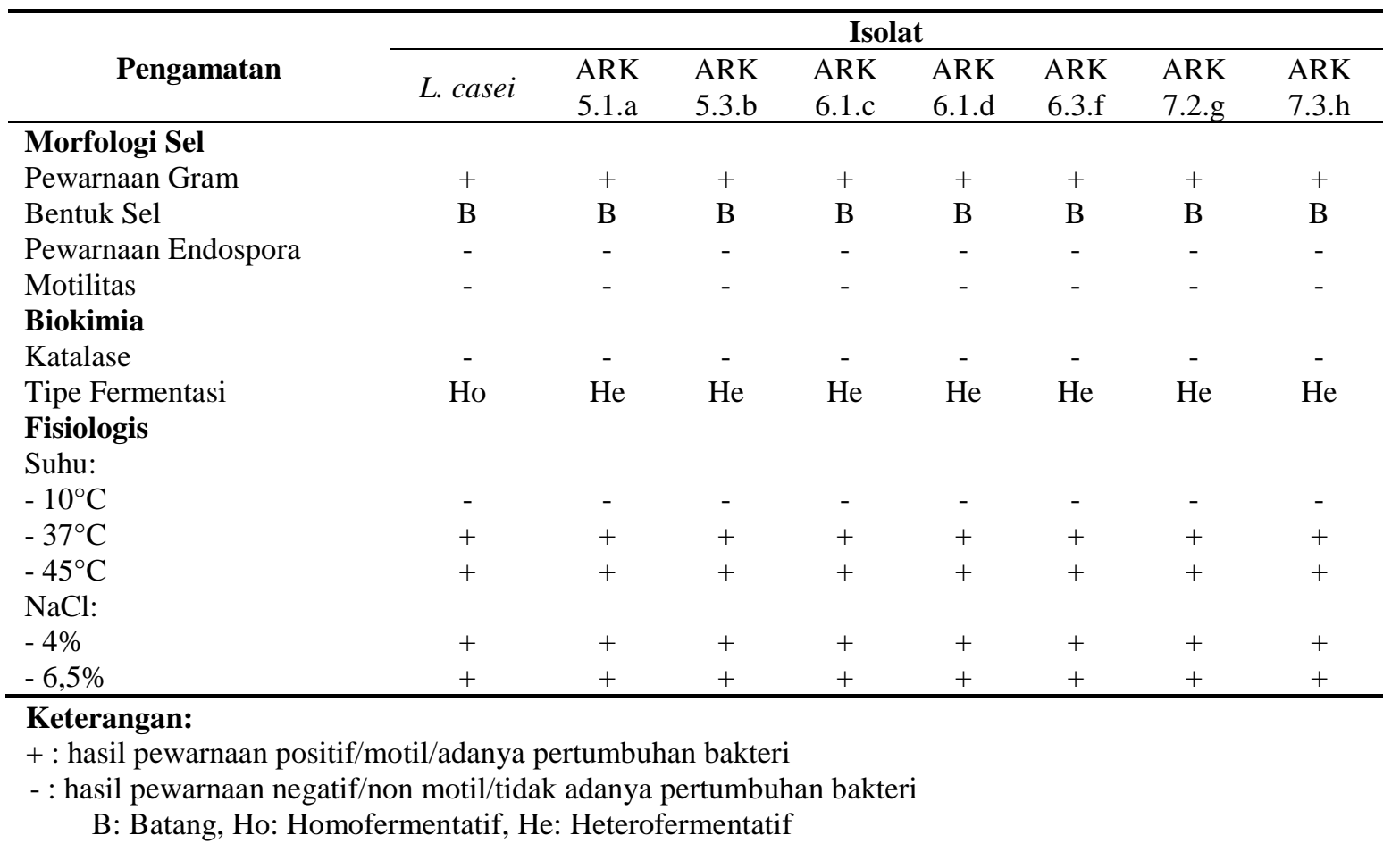

\section{Uji Keamanan Isolat Bakteri Asam Laktat}

Seperti yang disyaratkan oleh FAO/WHO pada tahun 2002, probiotik tidak boleh menyebabkan reaksi berbahaya dan aman terhadap sistem imun (dinyatakan aman atau status GRAS). Salah satu cara untuk melihat kemanan dari isolat BAL ini dengan melakukan uji aktivitas hemolisis menggunakan media blood agar. Pada uji aktivitas hemolisis digunakan Staphylococcus aureus sebagai kontrol positif, dengan hasil terdapat zona bening di sekitar koloni.

Zona bening yang terbentuk merupakan tanda adanya hemolisin, yaitu enzim yang bersifat toksik, dapat melisiskan sel darah merah, berperan dalam meningkatkan permeabilitas sel, sehingga sel lebih rentan terhadap agen infeksi (Khusnan et al., 2002). Pada penelitian ini, kedelapan isolat BAL tidak menunjukkan terjadinya hemolisis, baik terjadi perubahan warna media maupun terbentuk zona bening di sekitar koloni yang menandakan isolat BAL termasuk gamma hemolisis atau merupakan bakteri non patogen.

\section{KESIMPULAN}

Dalam penelitian "Isolasi Dan Karakterisasi Bakteri Asam Laktat Dari Limbah Cair Rendaman Kacang Kedelai" diperoleh delapan isolat yang berhasil diisolasi dari limbah cair rendaman kacang kedelai, tujuh diantaranya teridentifikasi sebagai
Bakteri Asam Laktat (BAL) yang diduga sebagai anggota genus Lactobacillus.

\section{DAFTAR PUSTAKA}

Anastiawan. 2014. Isolasi dan Karakterisasi Bakteri Probiotik yang Berasal dari Usus Itik Pedaging Anas domesticus. Skripsi: Universitas Hasanudin Makassar.

Aron, Nicoleta Maftei, Monica (Găureanu) Boev, dan Gabriela Bahrim. Probiotics and Therapeutic Effect in Clinical Practice Review. Romanian Biotechnological Letters, Vol. 20, No. 1, 2015.

Breed, Robert S., E.G.D. Murray, dan Nathan R. Smith. 1957. Bergeys's Manual of Determinative Bacteriology Seventh Edition. United States of America: The Williams \& Wilkins Company.

Bulut, Çisem. 2003. Isolation and Molecular Characterization of Lactic Acid Bacteria From Cheese. Tesis: Biotechnology and Bioengineering, İzmir Institute of Technology Turkey.

Desai, Ankur. 2008. Strain Identification, Viability and Probiotics Properties of Lactobacillus casei. Tesis: School of Biomedical and Health Sciences Victoria University Australia.

Dewi, Amalia Krishna. 2013. Isolasi, Identifikasi, dan Uji Sensitivitas Staphylococcus aureus 
terhadap Amoxicillin dari Sampel Susu Kambing Peranakan Ettawa (PE) Penderita Mastitis di Wilayah Girimulyo, Kulonprogo, Yogyakarta. Jurnal Sain Veteriner 31 (2), ISSN: 0126-0421.

Gogineni VK, Morrow LE, Gregory PJ, Malesker MA (2013) Probiotics: History and Evolution. J Anc Dis Prev Rem 1:107. doi:10.4172/2329-8731.1000107

Harley JP. Laboratory Exercises in Microbiology, Sixth Edition. New York: The McGraw-Hill Companies, Inc; 2005

Hidayat, Nur dan Sri Suhartini. Mikrobiologi Industri. Teknik Industri Pertanian FTP Universitas Brawijaya Malang;2006.

Khusnan, Wahyu Prihtiyantoro, dan Mitra Slipranata. Identifikasi dan Karakterisasi Fenotipe Staphylococcus aureus Asal Kasus Bumblefoot dan Arthritis pada Broiler. Jurnal Kedokteran Hewan Vol. 6 No. 2, September 2012 ISSN: 1978-225X.

Kormin, Salasiah, Gulam R, Son R, and Foo HL. Bacteriocin-Producing Lactic Acid Bacteria Isolated from Traditional Fermented Food. Malays J Med Sci. 2001 Jan; 8(1): 63-68.

Moreno M.R.F, J.J. Leisner, L.K. Tee, C. Ley, S. Radu, G. Rusul, M. Vancanneyt, and L. De Vuyst. Microbial Analysis of Malaysian Tempeh, and Characterization of Two Bacteriocins Produced by Isolates of Enterococcus faecium. J Appl Microbiol. 2002;92(1):147-57.

Ozyurt VH, Ötles S. Properties of probiotics and encapsulated probiotics in food. Acta Sci.Pol. Technol. Aliment., 2014, 13.4: 413424. DOI: $10.17306 /$ J.AFS.2014.4.8

Pisol B, Noriham A, Khalillah AK, dan Lilis N. Isolation and Identification of Lactic Acid Bacteria from Different Stages of Traditional Malaysian Tempeh production. Mal. J. Microbiol. Vol 11(4) 2015, pp. 358364.

Pisol, B, Lilis N, Noriham A, Suliantari, dan Khalilah AK. Isolation and Characterization of Lactic Acid Bacteria from Indonesian Soybean Tempe. IPCBEE vol.58 DOI: 10.7763/IPCBEE. 2013. V58. 7

Romadhon, Subagiyo, Sebastian M. Isolasi dan Karakterisasi Bakteri Asam Laktat dari Usus Udang Penghasil Bakteriosin Sebagai Agen Antibakteria Pada Produk-Produk Hasil Perikanan. Jurnal Saintek Perikanan Vol. 8. No. 1 . 2012.

Sopandi T dan Wardah. Mikrobiologi Pangan - Teori dan Praktik. Yogyakarta: Penerbit ANDI;2014.
Sun, Yalian, Xiuyu Lou, Xuan Zhu, Han Jiang, Qing $\mathrm{Gu}$. 2014. Isolation and Characterization of Lactic Acid Bacteria Producing Bacteriocin from Newborn Infants Feces. . J Bacteriol Mycol. 2014;1(2): 7.

Syafiq, A, Sauriasari R, Fikawati S, Amelia P, Soemijati A, Christy M, dan Saragih F. 2015. Effect of Inulin Supplemented UHT Milk Consumption on Faecal Bifidobacterium sp. And Lactobacillus sp. Of Healthy Children in Depok, Indonesia. Malaysian Journal of Nutrition 2015 Vol.21 No.2 pp.219-230 ref.19

Thakkar P, H.A. Modi, dan J.B. Prajapati. Isolation, Characterization, and Safety Assessment of Lactic Acid Bacterial Isolates from Fermented Food Products. Int.J.Curr.Microbiol.App.Sci (2015) 4(4): 713-725

Vandenplas Y, Huys G, Daube G. Probiotics: an update. J Pediatr (Rio J). 2015;91:6---21. 